\title{
ERRATUM
}

\section{Erratum to: The Fixed-Dose Combination of Olmesartan/Amlodipine Was Superior in Central Aortic Blood Pressure Reduction Compared with Perindopril/Amlodipine: A Randomized, Double-Blind Trial in Patients with Hypertension}

Luis Ruilope $\cdot$ Angie Schaefer

To view enhanced content go to www.advancesintherapy.com

Published online: February 11, 2014

(C) The Author(s) 2014. This article is published with open access at Springerlink.com

Erratum to: Adv Ther (2013) 30:1086-1099

DOI 10.1007/s12325-013-0076-6

The authors would like to make the following adjustment to the above mentioned article. The legends for Figs. 3 and 4 are incorrect and both should read "horizontal lines indicate the 95\% confidence intervals".
The online version of the original article can be found under doi:10.1007/s12325-013-0076-6.

L. Ruilope $(\square)$

Hypertension Unit, Hospital 12 de Octubre,

28041 Madrid, Spain

e-mail: ruilope@ad-hocbox.com

L. Ruilope

Department of Preventive Medicine and Public

Health, Universidad Autonoma, Madrid, Spain

A. Schaefer

Daiichi Sankyo Europe GmbH, Zielstattstrasse 48,

81379 Munich, Germany
Open Access. This article is distributed under the terms of the Creative Commons Attribution Noncommercial License which permits any noncommercial use, distribution, and reproduction in any medium, provided the original author(s) and the source are credited. 